organisms. Atypical bacteria have been described as a cause of lymphadenitis, particularly in children (Jones and Campbell, 1962; Marsden and Hyde, 1962). In adults, however, the reponted incidence is much less (Krishnaswami et al., 1972). In the present series atypical mycobacterial infection could not be implicated as the cause of drug failure in any of the patients. Similarly, none of the treatment failures in our series could be ascribed to infection with drug-resistant human-type organisms, and this has been an uncommon cause of treatment failure in other reported series.

It seems much more likely that drug treatment of tuberculous lymphadenitis can fail if inadequate tissue levels of antituberculosis drugs are obtained in lymph nodes. This is suggested by the quite common observation that tuberculous lymphadenitis may actually make its first appearance while a patient is having apparently effective antituberculosis therapy for a pulmonary or other lesion. This happened in two of the patients in our series and was also reported by Byrd et al. (1971). Tuberculous lymph nodes may also appear at one site when the patient is already having antituberculosis chemotherapy for diseased lymph nodes elsewhere (Newcombe, 1971).

In our view local excision biopsy should be undertaken to make the diagnosis and obtain material for bacteriological examination, culture, and sensitivity testing. Triple therapy with streptomycin, isoniazid, and rifampicin should be started immediately after operation and continued until the results of the drug sensitivities are known in about six weeks; streptomycin can then, if appropriate, be discontinued. Two-drug chemotherapy should then be continued for two years. In the event of a dubious increase in size of the lymph nodes or the appearance of new ones simply continuing chemotherapy may allow the nodes to subside without further intervention, but if they continue to enlarge or become fluctuant further excision should be carried out.

We wish to thank the physicians and surgeons of Westminster Hospital who have allowed us to study patients under their care.

\section{References}

Barrington-Ward, Sir Lancelot (1937). Lancet, 1, 980

Byrd, R. B., Pnpp, R. K., Gracey, D. R., and Purtiz, E. M. (1971). American Review of Respiratory Diseases, 103, 816.

Dowd, C. N. (1916). Fournal of the American Medical Association, 67, 499.

Fraser, H. S. (1965). British Fournal of Diseases of the Chest, 59, 164

German, J. L., Black, T. C., and Chapman, J. (1956). Diseases of the Chest, $30,326$.

Gillam, P. M., and Knowles, J. P. (1963). Tubercle, 44, 112

Gillam, P. M., and Knowles, J. P. (1963). Tubercle, 44, 112.

Hooper, A. A. (1972). British fournal of Surgery, 59, 353.

Jones, P. G., and Campbell, P. E. (1962). British fournal of Surgery, 50,

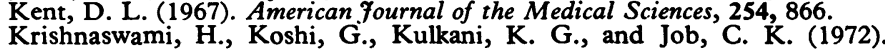
Tubercle, 53, 215 .

Marsden, H. B., and Hyde, W. A. (1962). Lancet, 1, 249.

Newcombe, J. F. (1971). Postgraduate Medical fournal, 47, 713.

Peel, A. L. G. (1972). British Fournal of Surgery, 59, 568.

Wilmot, T. J., James, E. F., and Reilly, L. V. (1957). Lancet, 2, 1184.

\title{
Benorylate in Management of Still's Disease
}

\author{
RICHARD H. POWELL, BARBARA M. ANSELL
}

British Medical fournal, 1974, 1, 145-147

\section{Summary}

The present recommended dose of benorylate is not satisfactory for the management of children suffering from inflammatory polyarthritis. A starting dose of $200 \mathrm{mg} / \mathrm{kg} / \mathrm{day}$ should be used, and the salicylate level checked at seven days and the dosage adjusted to give an anti-inflammatory effect-that is, a blood salicylate level of between 25 and $30 \mathrm{mg} / 100 \mathrm{ml}$. Once a satisfactory level has been achieved, this dosage should be maintained with occasional monitoring of the salicylate level. The paracetamol level does not need to be estimated as it tends to follow the salicylate level, provided that liver function is normal; thus it is quite safe to monitor only the salicylate level. Given in an adequate dosage, benorylate seems to be an acceptable salicylate preparation for use in juveniles suffering from chronic polyarthritis.

\section{Introduction}

Benorylate, an ester of aspirin and paracetamol, has been shown to be an effective analgesic anti-inflammatory drug in the treatment of adult rheumatoid arthritis. Beales et al. (1972) \footnotetext{
M.R.C. Rheumatism Unit, Canadian Red Cross Memorial Hospital,
Taplow, Maidenhead, Berks

RICHARD H. POWELL, B.M, B.S., Senior House Officer

BARBARA M. ANSELL, M.D., F.R.C.P., Consultant Rheumatologist
}

found it equivalent to aspirin, with a lower incidence of side effects. It has also been compared favourably with phenylbutazone (Haslock et al., 1971) and indomethacin (Franke and Manz, 1972), and has been shown to cause less gastrointestinal bleeding than aspirin (Croft et al., 1972). A dosage in the order of 100 $\mathrm{mg} / \mathrm{kg}$ is required to obtain an adequate effect.

Chronic polyarthritis in childhood is relatively rare. There are a number of types but the most usual is a form of chronic seronegative polyarthritis usually designated Still's disease in Britain. In the management of such children, despite the introduction of many new drugs, salicylates still remain the treatment of choice (Ansell, 1972).

In general, aspirin preparations are better tolerated by children than by adults, with a much lower incidence of side effects. However, gastrointestinal symptoms and occasionally bleeding can arise. The doses of benorylate currently recommended for children (table I) are based on its analgesic not its anti-inflammatory action and are well below the suggested dosage for adults with rheumatoid arthritis. Because of this it was decided to investigate salicylate and paracetamol levels in children with Still's disease receiving benorylate.

\begin{tabular}{c|c} 
TABLE I-Benorylate Dose Currently Recommended for Children \\
\hline Age & Maximum Recommended Daily Dose \\
\hline 3 months-1 year & $100 \mathrm{mg} / \mathrm{kg}(0.25 \mathrm{ml} / \mathrm{kg})$ \\
$1-2$ years & $1.0 \mathrm{~g}(2.5 \mathrm{ml})$ \\
$3-5$ years & $\begin{array}{c}1.5 \mathrm{~g}(3.75 \mathrm{ml}) \\
6-12 \text { years }\end{array}$ \\
& $2.0 \mathrm{~g}(5.0 \mathrm{~m} !)$ \\
\hline
\end{tabular}

\section{Method}

The children under study were all inpatients at this hospital 
suffering from active Still's disease. A pilot study was undertaken in eight patients aged from 6 to 15 years. The only change in management was that benorylate was given instead of their usual salicylate preparation. The first three children received the recommended dosage of not more than $2 \mathrm{~g}(5 \mathrm{ml}) /$ day. As the blood salicylate levels were low the remaining five older or larger children were given twice the recommended dosage. The results were not encouraging in that there was recurrence of soft tissue swelling and a reduction in functional capacity. This was thought to be due to the low blood salicylate levels compared with those of between 25 and $35 \mathrm{mg} / 100 \mathrm{ml}$ normally required for effective treatment (table II). As the paracetamol levels were not unduly high it was decided to undertake a further study of such patients, increasing the dose of benorylate to about 200 $\mathrm{mg} / \mathrm{kg} /$ day to see if an increased dose would make the drug effective in this disorder.

The second study consisted of 12 inpatients aged from 4 to 13 years. Two of these had participated in the pilot study, and a further two were already taking benorylate when admitted. The other eight were either on Nu-Seals aspirin or Palaprin in maximum tolerated dosage. The weight of the patient and the dosage of aspirin before the trial and of benorylate during the trial are shown in table III.

None of the children had abnormal levels of blood urea or proteinuria, and all of them had normal liver function as judged by serum alanine and aspartate transaminase levels. Except for the two children previously in the pilot study and the two already on benorylate all were treated for one week with twice the recommended dose for children. If at the end of this period the salicylate levels were not adequate and the clinical state was not maintained or improving the dosage was increased to a maximum of about $200 \mathrm{mg} / \mathrm{kg} /$ day for a further two weeks. During this time the salicylate levels were measured weekly. Plasma samples were taken and stored for paracetamol levels to be measured later, with the exception that if a high salicylate blood level was obtained the paracetamol levels were immediately estimated on that sample. Salicylate estimations were perfomed by the method of Trinder (1954).

Clinical assessments consisted of grip strength and walking time and were made twice weekly at the same time on each occasion, while a joint check, noting change in involvement with particular reference to soft tissue swelling, was also performed.
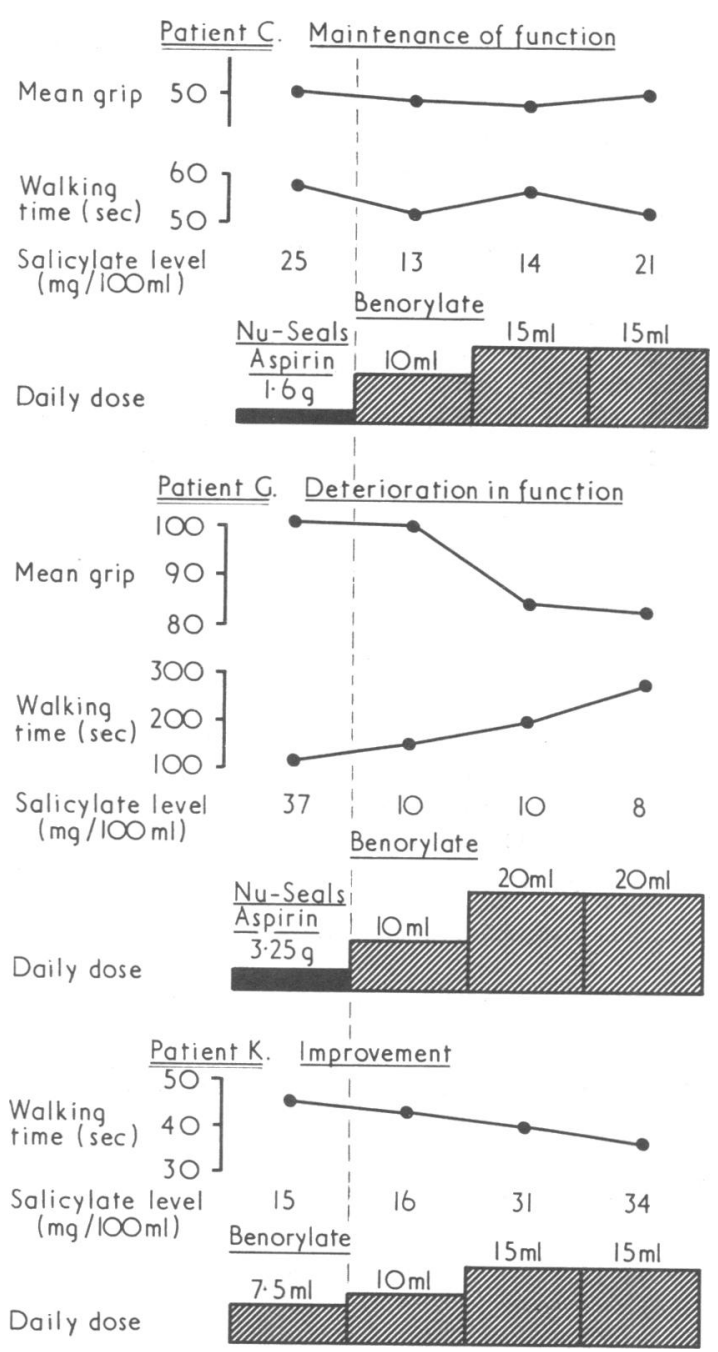

Variation in functional ability and grip strength with salicylate level in patients $\mathrm{C}$ (maintenance), $\mathrm{G}$ (deterioration), and $\mathrm{K}$ (improvement). The methods used are explained in the text.

TABLE II-Results of Pilot Study on Eight Children given Benorylate instead of their Usual Salicylate Preparation

\begin{tabular}{|c|c|c|c|c|c|c|c|}
\hline \multirow{2}{*}{ Patient No. } & \multirow{2}{*}{ Age (Years) } & \multirow{2}{*}{ Weight (kg) } & \multirow{2}{*}{ Daily Dose (ml) } & \multicolumn{2}{|c|}{ After 1 Week } & \multicolumn{2}{|c|}{ After 2 Weeks } \\
\hline & & & & $\begin{array}{c}\text { Salicylate } \\
\text { (mg/100 ml) }\end{array}$ & $\begin{array}{c}\text { Paracetamol } \\
(\mu \mathrm{g} / \mathrm{ml})\end{array}$ & $\begin{array}{c}\text { Salicylate } \\
(\mathbf{m g} / 100 \mathrm{ml})\end{array}$ & $\underset{(\mu \mathrm{g} / \mathrm{ml})}{\text { Paracetamol }}$ \\
\hline $\begin{array}{l}1 * \\
2^{*} \\
3 \\
4 \\
5 \\
6 \\
7 \\
8\end{array}$ & $\begin{array}{r}6 \\
9 \\
7 \\
7 \\
11 \\
12 \\
12 \\
12\end{array}$ & $\begin{array}{l}16 \\
19 \cdot 5 \\
27 \cdot 4 \\
30 \cdot 2 \\
34 \cdot 1 \\
27 \cdot 7 \\
43 \cdot 9 \\
53 \cdot 6\end{array}$ & $\begin{array}{r}5 \\
5 \\
5 \\
10 \\
10 \\
10 \\
10 \\
10\end{array}$ & $\begin{array}{r}9 \\
6 \\
11 \\
15 \\
21 \\
26 \\
20 \\
9\end{array}$ & $\begin{array}{r}3.6 \\
2.2 \\
8.6 \\
10.2 \\
11.3 \\
8.9 \\
3.6 \\
14.02\end{array}$ & $\begin{array}{r}3 \\
2 \\
8 \\
6 \\
6 \cdot 5 \\
6.9 \\
18 \\
20\end{array}$ & $\begin{array}{r}4.7 \\
2.5 \\
2.2 \\
1.9 \\
9.9 \\
11.3 \\
4.7 \\
4.7\end{array}$ \\
\hline
\end{tabular}

*Patients 1 and 2 also included in main study as patients $\mathrm{D}$ and $\mathrm{J}$.

TABLE III-Clinical Data and Treatment in the 12 Children Under Study

\begin{tabular}{|c|c|c|c|c|c|c|c|}
\hline \multirow{2}{*}{ Patient } & \multirow{2}{*}{ Age (years) } & \multirow{2}{*}{ Weight (kg) } & \multirow{2}{*}{$\begin{array}{l}\text { Previous Therapy } \\
\text { and Daily Dose (g) }\end{array}$} & \multirow{2}{*}{$\begin{array}{c}\text { Preliminary } \\
\text { Benorylate } \\
\text { Dose (ml) }\end{array}$} & \multicolumn{3}{|c|}{ Daily Dose of Benorylate (ml) } \\
\hline & & & & & First Week* & Second Week & Third Week \\
\hline $\begin{array}{l}\mathbf{A} \\
\mathbf{B} \\
\mathbf{C} \\
\mathbf{D} \\
\mathbf{E} \\
\mathbf{F} \\
\mathbf{G} \\
\mathbf{H} \\
\mathbf{I} \\
\mathbf{J} \\
\mathbf{K} \\
\mathbf{L}\end{array}$ & $\begin{array}{r}11 \\
8 \\
8 \\
6 \\
12 \\
10 \\
12 \\
8 \\
12 \\
10 \\
4 \\
13\end{array}$ & $\begin{array}{l}29 \cdot 5 \\
22 \cdot 75 \\
18 \cdot 5 \\
18 \cdot 0 \\
35 \cdot 5 \\
29 \cdot 0 \\
37 \cdot 0 \\
17 \cdot 0 \\
31 \cdot 0 \\
21 \cdot 0 \\
22 \cdot 0 \\
29 \cdot 0\end{array}$ & $\begin{array}{c}\text { Nu-Seals }(2 \cdot 6) \\
\text { Nu-Seals }(2 \cdot 3) \\
\text { Nu-Seals }(1 \cdot 6) \\
\text { Palaprin }(1 \cdot 75) \\
\text { Nu-Seals }(2 \cdot 6) \\
\text { Palaprin }(3 \cdot 0) \\
\text { Nu-Seals }(3 \cdot 25) \\
\text { Nu-Seals }(1 \cdot 3) \\
\text { Nu-Seals }(2 \cdot 3) \\
\text { Nu-Seals }(2 \cdot 0) \\
\text { Benorylate } \\
\text { Benorylate }\end{array}$ & $\begin{array}{l}5 \\
7 \cdot 5 \\
10\end{array}$ & $\begin{array}{l}10 \\
10 \\
10 \\
10 \\
10 \\
10 \\
10 \\
10 \\
10 \\
10 \\
10 \\
20\end{array}$ & $\begin{array}{l}20 \\
20 \\
15 \\
10 \\
20 \\
15 \\
20 \\
10 \\
20 \\
20 \\
15 \\
20\end{array}$ & $\begin{array}{l}20 \\
20 \\
15 \\
10 \\
20 \\
15 \\
20 \\
10 \\
20 \\
20 \\
15 \\
20\end{array}$ \\
\hline
\end{tabular}


TABLE IV-Salicylate and Paracetamol Levels in the 12 Children Under Study

\begin{tabular}{|c|c|c|c|c|c|c|c|c|c|}
\hline \multirow{2}{*}{ Patient } & \multirow{2}{*}{$\begin{array}{c}\text { Salicrlate } \\
\text { Level before } \\
\text { Trial } \\
(\mathrm{mg} / 100 \mathrm{ml})\end{array}$} & \multicolumn{2}{|c|}{ Preliminary } & \multicolumn{2}{|c|}{ After 1 Week } & \multicolumn{2}{|c|}{ After 2 Weeks } & \multicolumn{2}{|c|}{ After 3 Weeks } \\
\hline & & $\begin{array}{c}\text { Salicvlate } \\
\text { (mg;'100 ml) }\end{array}$ & $\begin{array}{c}\text { Paracetamol } \\
(\mu \mathrm{g} / \mathrm{ml})\end{array}$ & $\begin{array}{c}\text { Salicylate } \\
(\mathrm{mg} / 100 \mathrm{ml})\end{array}$ & $\begin{array}{c}\text { Paracetamol } \\
(\mu \mathrm{g} / \mathrm{ml})\end{array}$ & $\begin{array}{c}\text { Salicvlate } \\
(\mathrm{mg} / 100 \mathrm{ml})\end{array}$ & $\begin{array}{c}\text { Paracetamol } \\
(\mu \mathrm{g} / \mathrm{ml})\end{array}$ & $\begin{array}{c}\text { Salicvlate } \\
\text { (mg/100 ml) }\end{array}$ & $\begin{array}{c}\text { Paracetamol } \\
(\mu \mathrm{g} / \mathrm{ml})\end{array}$ \\
\hline $\begin{array}{l}\mathbf{A} \\
\mathbf{B} \\
\mathbf{C}\end{array}$ & $\begin{array}{l}41 \\
36 \\
25\end{array}$ & & & $\begin{array}{r}10 \\
9 \\
13\end{array}$ & $\begin{array}{l}4 \cdot 2 \\
6 \cdot 4 \\
6 \cdot 6\end{array}$ & $\begin{array}{l}23 \\
16 \\
14\end{array}$ & $\begin{array}{r}10.1 \\
8.7 \\
6.3\end{array}$ & $\begin{array}{l}22 \\
13 \\
21\end{array}$ & $\begin{array}{l}7 \cdot 0 \\
5.8 \\
6.2\end{array}$ \\
\hline D & 33 & 17 & $\begin{array}{l}4.7 \\
1.6\end{array}$ & 28 & $10 \cdot 5$ & 16 & $10 \cdot 8$ & 18 & $\mathbf{8 \cdot 2}$ \\
\hline $\begin{array}{l}\mathbf{E} \\
\mathbf{F} \\
\mathbf{G} \\
\mathbf{H} \\
\mathbf{I} \\
\mathbf{J} \\
\mathbf{K} \\
\mathbf{L}\end{array}$ & $\begin{array}{l}22 \\
29 \\
37 \\
28 \\
32 \\
31 \\
=\end{array}$ & $\begin{array}{r}7 \\
15 \\
3\end{array}$ & $\frac{2.5}{=}$ & $\begin{array}{l}12 \\
22 \\
10 \\
27 \\
19 \\
14 \\
16 \\
11\end{array}$ & $\begin{array}{r}9.5 \\
17.9 \\
8.0 \\
2.4 \\
7.0 \\
6.3 \\
3.9 \\
6.3\end{array}$ & $\begin{array}{l}15 \\
28 \\
10 \\
29 \\
21 \\
27 \\
31 \\
15\end{array}$ & $\begin{array}{r}11.9 \\
17.5 \\
10.8 \\
9.8 \\
12.3 \\
8.7 \\
6.6 \\
15.0\end{array}$ & $\begin{array}{r}15 \\
13 \\
8 \\
17 \\
16 \\
20 \\
34 \\
22\end{array}$ & $\begin{array}{r}11.0 \\
6.2 \\
8.8 \\
3.8 \\
8.2 \\
8.8 \\
6.6\end{array}$ \\
\hline
\end{tabular}

*Preliminary data relate to previous Benorylate therapy.

\section{Results}

In general the salicylate level rose with the increased dosage, and the paracetamol level tended to increase parallel with the salicylate level (table IV). Despite increasing the dosage, a satisfactory salicylate level was achieved in only a few patients. Towards the end of the trial the transaminases were measured in each patient and all were normal. The functional ability and grip strength showed some variation with the salicylate level. In general when this fell there tended to be some fall off in function, while when it was satisfactorily maintained this tended to remain much the same or to improve, when the salicylate level increased (graph).

\section{Discussion}

Despite doubling the recommended dosage of benorylate adequate blood salicylate levels were not achieved in most patients. This was reflected in a decrease in functional ability during the trial period. A few of the children obtained satisfactory blood levels, but there was no correlation between levels obtained and dosage in $\mathrm{mg} / \mathrm{kg}$. Many studies have shown the variability between normal subjects of the serum level of salicylate reached after equivalent doses of various aspirin preparations. The variability in one particular subject is usually thought to be small, though Rowland et al. (1972) found a twofold difference in the peak plasma level obtained by one normal male subject after two separate administrations of $650 \mathrm{mg}$ aspirin in solution.

Some controversy exists as to any overall difference in the serum salicylate of patients with rheumatoid arthritis and non-rheumatoid subjects after equivalent salicylate dosage. Fremont-Smith et al. (1961) found that patients with active rheumatoid disease had an average plasma salicylate concentration of about half of that of a group with inactive disease even after intravenous administration. The plasma half life in rheumatoid arthritis was appreciably shorter than in normal subjects but this difference disappeared when the normal controls who were ambulatory were also confined to bed like the rheumatoid patients.

Baum (1970) found identical plasma levels of salicylate in patients with rheumatoid arthritis and those with degenerative joint disease, and attributed this to equivalent degrees of mobility in his patients. Bayles (1966) in a review article commented that chronic ingestion of aspirin for two months by normal volunteers did not alter the plasma level, and he thought it was unlikely to do so in rheumatoid patients. Further work discussed by Bayles in this review showed that in rheumatoid patients a smaller amount of salicylate is present in the plasma than in normals, but a larger amount is in the interstitial fluid, and that these figures give the same total in the extracellular fluid of the body in both rheumatoid arthritics and normal subjects. It may be that the lower plasma concentrations in rheumatoid patients may be due to the hypoalbuminaemia that is often found in patients with active disease.

Evidence exists that absorption from the gut is impaired in rheumatoid arthritics as judged by the xylose absorption test and faecal fat (Dyer et al., 1971). In that study the small-bowel morphology was normal but other workers have shown that secondary amyloidosis of the small intestine can occur in patients with rheumatoid arthritis (Pettersson and Wegelius, 1972) and this may contribute to malabsorption.

None of the children in the trial had evidence of amyloidosis. Though malabsorption has not been found in children with Still's disease without amyloidosis this could be a factor in the low plasma salicylate levels achieved with high benorylate dosage.

None of the children in this series had any side effects from benorylate.

At the present time we would recommend that benorylate used in Still's disease should be started with a dosage of $\mathbf{2 0 0}$ $\mathrm{mg} / \mathrm{kg} /$ day and the salicylate level checked at seven days and the dosage adjusted to give an anti-inflammatory effect-that is, a blood salicylate level of between 25 and $30 \mathrm{mg} / 100 \mathrm{ml}$. Once a satisfactory level has been achieved, this dosage should be maintained with occasional monitoring of the salicylate level.

We are grateful to the Sterling-Winthrop Group Ltd. for their help with this work and in particular for Dr. Savage's and Dr. Margett's arrangements for the paracetamol levels to be estimated in their laboratories.

Requests for reprints should be addressed to: Dr. B. M. Ansell, M.R.C. Rheumatism Unit, Canadian Red Cross Memorial Hospital, Taplow, Maidenhead, Berks.

\section{References}

Ansell, B. M. (1972). Practitioner, 208, 91.

Baum, J. (1970). Fournal of Clinical Pharmacology, 10, 352

Bayles, T. B. (1966). Arthritis and Rheumatism, 9, 342 .

Beales, D. L., Burry, H. C., and Grahame, R (1972). British Medical Fournal, $2,483$.

Croft, D. N., Cuddigan, J. H. P., and Sweetland, C. (1972). British Medical Fournal, 3, 545 .

Dyer, N. H., Kendall, M. J., and Hawkins, C. F. (1971). Annals of Rheumatic Diseases, 30, 626

Franke, M., and Manz, G. (1972). Current Therapeutic Research, 14, 113.

Fremont-Smith, K., et al. (1961). In X Congresso della Lega Internazionale Contro Il Reumatismo, vol. 2, 1342. Turin, Minerva Medica.

Haslock, D. I., Nicholson, P. A., and Wright, V. (1971). Clinical Trials Fournal, 8, 43.

Pettersson, T., and Wegelius, O. (1972). Gastroenterology, 62, 22.

Rowland, M., Riegelman, S., Harris, P. A., and Sholkoff, S. D. (1972). fournal of Pharmaceutical Sciences, 61, 379.

Trinder, P. (1954). Biochemical fournal, 57, $30 \mathrm{i}$ 